(1)

George Fox

UNIVERSITY
Digital Commons @ George Fox University

Faculty Publications - Department of Biology and Chemistry

Department of Biology and Chemistry

2019

Environmental Determinants of Recruitment Success of Subalpine Fir (Abies Lasiocarpa) in a Mixed-Conifer Forest

Elizah Z. Stephens

Christopher P. Murar

Daniel B. Tinker

Paige E. Copenhaver-Parry

Follow this and additional works at: https://digitalcommons.georgefox.edu/bio_fac

Part of the Biology Commons 


\title{
Environmental determinants of recruitment success of subalpine fir (Abies lasiocarpa) in a mixed-conifer forest
}

\author{
Elizah Z. Stephens ${ }^{1}$, Christopher P. Murar ${ }^{1}$, Daniel B. Tinker ${ }^{2}$, and Paige E. Copenhaver-Parry ${ }^{1, *}$ \\ ${ }^{1}$ Department of Biology, George Fox University, Newberg, OR 97132 \\ ${ }^{2}$ Program in Ecology and Department of Botany, University of Wyoming, Laramie, WY 82071
}

\begin{abstract}
Understanding the processes that underlie forest resilience is of increasing importance as climate change and shifting disturbance regimes continue to impact western forests. Forest research and management efforts within the low-diversity conifer forests of the U.S. Rocky Mountains have typically focused on relatively monotypic stands dominated by a single cohort, but mixed-conifer stands, such as those codominated by Abies lasiocarpa and Pinus contorta have been less widely studied. The presence of A. lasiocarpa may enhance resilience to fire- and mountain pine beetle-induced mortality and depends on successful A. lasiocarpa recruitment under a range of environmental conditions. The purpose of this study was to quantify the effects of key forest structural characteristics and environmental conditions on recruitment of A. lasiocarpa in a midelevation mixed-conifer forest in the central Rocky Mountains. To address this aim, A. lasiocarpa seedling density, light availability, neighborhood basal area, and soil fertility were measured across 24 plots, and the relative effects of each measured variable, temperature, and precipitation on seedling density were quantified within a Bayesian multilevel regression model. Model results showed nonsignificant effects of climate, light availability, and neighborhood index on seedling density; a significant positive association between seedling density and the interaction between soil fertility and neighborhood index; and a strong negative relationship between seedling density and soil fertility. We posit that the negative association with soil fertility in these nutrient-poor forests reflects an underlying gradient in soil moisture availability that corresponds with water flux pathways. Ultimately, much of the variance in seedling densities was explained by latent plot and year effects, indicating that A. lasiocarpa establishment in this mixed-conifer forest is likely governed by a complex suite of environmental factors that vary across fine spatiotemporal scales.
\end{abstract}

Resumen.-A medida que el cambio climático y los regímenes de perturbación continúan impactando los bosques occidentales, se vuelve cada vez más importante comprender los procesos que subyacen a la resiliencia de los bosques. En general, los esfuerzos de conservación y de investigación forestal, dentro de los bosques de coníferas de baja diversidad en las Montañas Rocallosas (Rocky Mountains, EE.UU.), se han enfocado, en los rodales relativamente monotípicos dominados por un sólo grupo. Los rodales de coníferas mixtas, tales como los codominados por Abies lasiocarpa y Pinus contorta, han sido menos estudiados. La presencia de A. lasiocarpa puede promover la resistencia a los incendios y a la mortalidad inducida por el escarabajo de pino de montaña. No obstante, el reclutamiento exitoso de A. lasiocarpa depende de diversas condiciones ambientales. El objetivo de este estudio fue cuantificar los efectos de las características estructurales clave de los bosques y de las condiciones ambientales en el reclutamiento de A. lasiocarpa en un bosque de coníferas mixtas de mediana elevación, en el centro de las Montañas Rocallosas. Para lograr este objetivo, se midió la densidad de plántulas de A. lasiocarpa, la disponibilidad de luz, el área basal del vecindario y la fertilidad del suelo en 24 parcelas. El efecto relativo de cada variable medida (1) temperatura, (2) precipitación, y (3) densidad de plántulas, fueron cuantificados mediante un modelo bayesiano de regresión múltiple. Los resultados del modelo mostraron efectos no significativos del clima, de la disponibilidad de la luz y del índice de proximidad al vecindario en la densidad de las plántulas. Sin embargo, el modelo muestra una relación positiva significativa entre la densidad de las plántulas y la interacción entre la fertilidad del suelo y el índice de proximidad al vecindario, así como una fuerte relación negativa entre la densidad de las plántulas y la fertilidad del suelo. Sugerimos que la asociación negativa con la fertilidad del suelo en estos bosques pobres en nutrientes refleja un gradiente subyacente en la disponibilidad de humedad del suelo que corresponde con las vías del flujo de agua. Finalmente, gran parte de la variación de la densidad de plántulas fue explicada por los efectos del año y de las parcelas latentes, indicando que el establecimiento de A. lasiocarpa en este bosque de coníferas mixtas probablemente se rija por un conjunto complejo de factores ambientales que varían a través de pequeñas escalas espaciotemporales.

*Corresponding author: pparry@georgefox.edu 
As climate change progresses, western forests are increasingly threatened by an increase in the frequency and severity of disturbance events such as fire and insect outbreaks (Dale et al. 2001, Johnstone et al. 2004, Nitschke and Innes 2008, Collins et al. 2010, Buma and Wessman 2011, Bell et al. 2014, Agne et al. 2016). Consequently, the need to understand the mechanisms that underlie and promote forest resilience, such as postdisturbance recovery dynamics, is becoming increasingly urgent. Forest resilience refers to the capacity of an ecosystem to return to a predisturbance state that may be characterized by long-term maintenance of forest structure, species composition, or ecosystem function (Holling 1973). Resilience has long been recognized to be closely dependent on biodiversity (Hooper et al. 2005). In particular, forest structural heterogeneity and species diversity may be uniquely important characteristics for promoting forest resilience through mechanisms including increased productivity, functional compensation, and differential susceptibility to disturbance agents (Naeem 1998, Yachi and Loreau 1999, Pretzche 2005, Kayes and Tinker 2012).

In the elevationally stratified and relatively low-diversity forests of the U.S. Rocky Mountains, forests consisting primarily of a single dominant overstory species are often the focus of forest management efforts, harvesting activities, postdisturbance recovery studies, and conservation initiatives (Colorado Forestry Advisory Board 2006, Collins et al. 2010, 2011, Donato et al. 2013, Fornwalt et al. 2018). However, substantial overlap in species distributions exists across this region (Copenhaver-Parry and Cannon 2016, CopenhaverParry and Bell 2018), giving rise to heterogeneous mixed-species forests that may play an important role in promoting landscape-level forest resilience (Turner 2010, Turner et al. 2013). In particular, midelevation mixedconifer forests consisting primarily of Pinus contorta (lodgepole pine) and Abies lasiocarpa (subalpine fir) cover a substantial portion of the Rocky Mountain region of western North America (Fig. 1). The structural heterogeneity in mixed-conifer stands is primarily generated by $A$. lasiocarpa, as $P$. contorta establishment most commonly occurs in evenaged cohorts following fire (Day 1972, Veblen 1986), whereas A. lasiocarpa, a shade-tolerant, later-successional species, establishes readily in the understory of even-aged $P$. contorta stands (Day 1972, Veblen 1986, Stohlgren et al. 1998, Kayes and Tinker 2012). The presence of $A$. lasiocarpa in these midelevation forests may contribute substantially to the maintenance of forest resilience, particularly in light of the susceptibility of $P$. contorta to mountain pine beetle (Dendroctonus ponderosae) and changing fire regimes, to which serotinous $P$. contorta may be unable to readily adapt (Greene et al. 1999, Schoennagel et al. 2003, Johnstone and Chapin 2006).

Historically, resilience and postdisturbance recovery of mixed-conifer forests has been attributable to release of abundant $P$. contorta seeds from serotinous cones following fire and subsequent rapid recruitment (Turner et al. 2016), and to strong postdisturbance recruitment of spruce, fir, and aspen, often through advance regeneration (Johnstone et al. 2004, Schoennagel et al. 2011, Kayes and Tinker 2012, Harvey et al. 2016). However, fire frequency and severity are predicted to increase with climate change across fire-prone forests, and larger and more frequent insect outbreaks are projected to drive massive forest mortality, changes that will likely alter the successional dynamics of these forests (Dale et al. 2001, Meddens et al. 2008, Flannigan et al. 2009, Westerling et al. 2011). Compared to monospecific stands, mixed-species forests with heterogeneous age structures are more resilient to both beetle mortality and fires, returning to predisturbance states more quickly than more homogenous stands (DeRose and Long 2007, Agne et al. 2016). For example, A. lasiocarpa advance regeneration following mountain pine beetle outbreak in mixedconifer forests supports rapid recovery of forest productivity and function and enhances species diversity, thereby promoting resilience to future mountain pine beetle outbreaks (Kayes and Tinker 2012). The ability of wind-dispersed A. lasiocarpa to disperse its seeds at a greater distance than $P$. contorta is also an important factor in maintaining forest resilience following compound or severe disturbances (Noble and Ronco 1978, Alexander et al. 1990). Although high-temperature fires may consume the serotinous cones of $P$. contorta, the longer dispersal distance of $A$. lasiocarpa seed may allow A. lasiocarpa to establish in severely disturbed areas (Buma and Wessman 2011). 


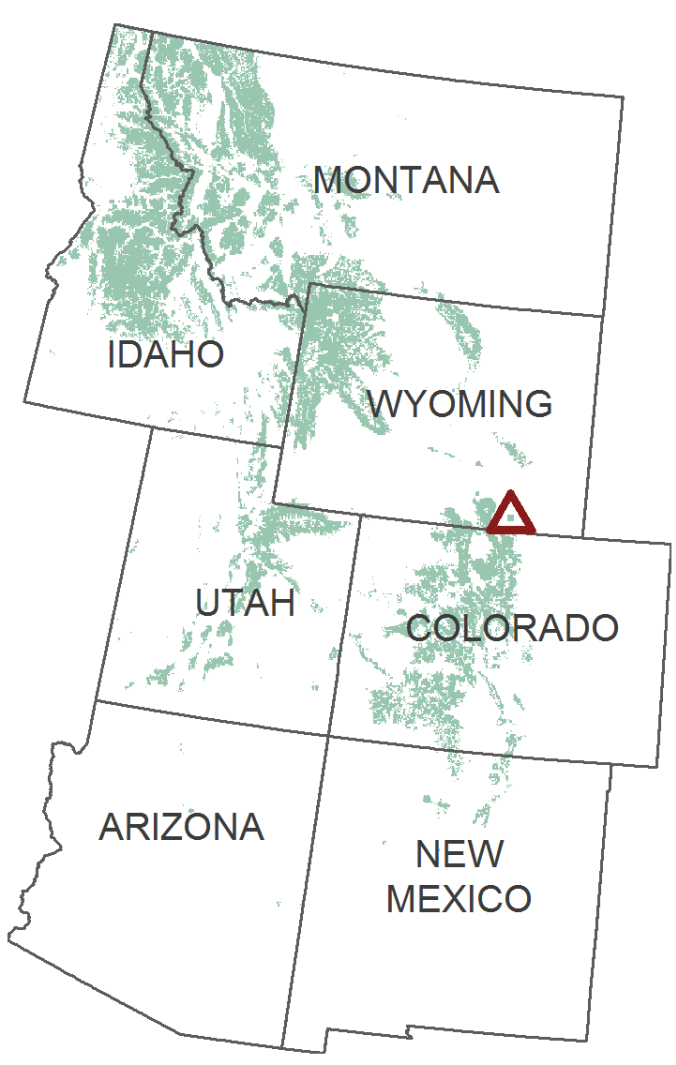

Fig. 1. The distribution of mixed-conifer Pinus contortaAbies lasiocarpa forests across the U.S. Rocky Mountains. The study site is denoted by the red triangle. Distribution data are taken from Copenhaver-Parry and Bell (2018).

The persistent contribution of A. lasiocarpa to forest resilience in midelevation mixedconifer forests depends upon successful and sustained seedling recruitment, which includes the processes of seed arrival, seedling germination, and seedling establishment. However, the factors influencing A. lasiocarpa recruitment success are primarily understood for subalpine spruce-fir forests codominated by A. lasiocarpa and Picea engelmanii, and the environmental drivers of $A$. lasiocarpa recruitment in mixed-conifer $P$. contorta-A. lasiocarpa forests have been generally overlooked. Studies from spruce-fir forests indicate that A. lasiocarpa seedlings are highly shade-tolerant, often capable of establishing under high canopy cover in understory solar radiation levels of $<2 \mathrm{MJ} / \mathrm{m}^{2}$ per day and maintaining relatively high photosynthesis rates in these low light conditions (Knapp and Smith 1982,
Maher and Germino 2006). This may reflect a high sensitivity to moisture limitation, particularly considering the late-spring germination of A. lasiocarpa and corresponding high summer mortality (Knapp and Smith 1982, Maher and Germino 2006). Indeed, seedling survival is dramatically enhanced in microsites with high soil moisture in mixed-species A. lasiocarpa-Populus tremuloides stands (Buck and St. Clair 2014). Soil moisture may be modulated by a variety of stand characteristics including proximity to adult trees (Calder and St. Clair 2012, Buck and St. Clair 2014), canopy density (Maher and Germino 2006), and substrate type (LePage et al. 2000). Ultimately, however, information regarding the factors that influence recruitment of A. lasiocarpa in drier, lower-elevation mixed-conifer P. contorta-A. lasiocarpa stands is scarce.

The purpose of this study was to quantify the effects of forest structural characteristics and environmental conditions on recruitment of A. lasiocarpa in a midelevation mixedconifer forest consisting primarily of $P$. contorta and A. lasiocarpa. We sought to investigate the relative effects of light availability, soil fertility, neighborhood structure, temperature, and precipitation on the density of A. lasiocarpa seedlings. Consistent with findings from higherelevation spruce-fir forests, we hypothesized that microsite characteristics including soil fertility and light availability may have a stronger influence on A. lasiocarpa seedling density than stand-level variables including temperature and precipitation due to the high sensitivity of A. lasiocarpa seedlings to local resource availability. By identifying the fine-scale drivers of variation in A. lasiocarpa recruitment, we hope to improve understanding of the mechanisms that maintain structural heterogeneity and species diversity, and thereby contribute to resilience in this midelevation mixed-conifer forest.

\section{Methods}

\section{Study Area}

This study was conducted within a mixedconifer forest located between $2250 \mathrm{~m}$ and $2450 \mathrm{~m}$ above sea level on Pole Mountain, which lies within the Medicine Bow National Forest in the Laramie Mountain Range on the eastern edge of the central Rocky Mountains in Wyoming. This forest was selected primarily 


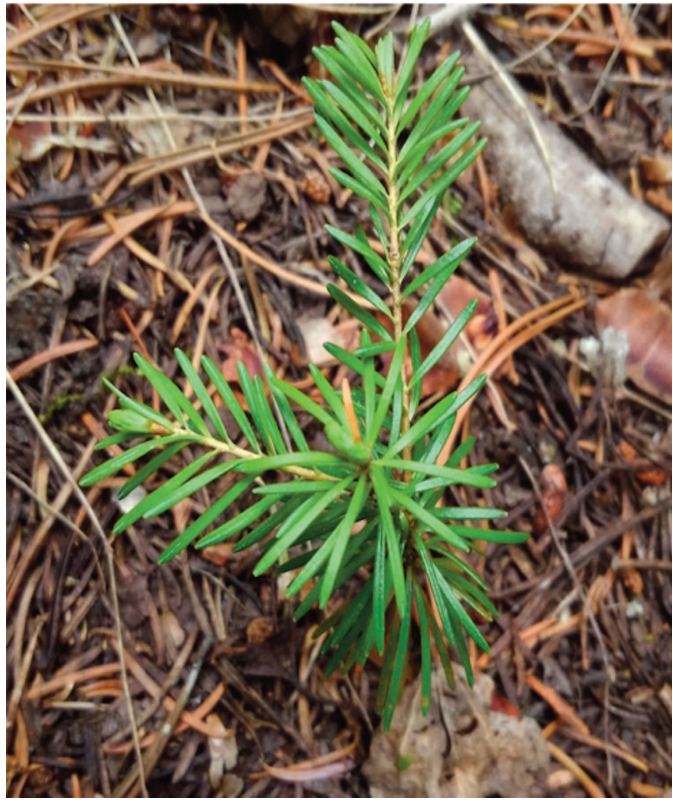

Fig. 2. An Abies lasiocarpa seedling in one of the seedling plots included in the study.

because of its low mountain pine beetle-caused mortality, despite an extensive mountain pine beetle epidemic in the region. The forest was dominated by $P$. contorta and A. lasiocarpa, with limited $P$. tremuloides and $P$. engelmannii throughout the understory, and Pinus flexilis occurring along forest edges. The majority of the $P$. contorta individuals established following large fires in 1922 and 1948, while A. lasiocarpa establishment has occurred primarily in a recent relatively fire-free period beginning in 1948 (C. Murar unpublished data). Seedling composition across the study plots was dominated by A. lasiocarpa (Fig. 2), with a small number of $P$. engelmannii, $P$. flexilis, and $P$. contorta seedlings (Table 1). Average monthly temperatures in the study area range from $-5.9{ }^{\circ} \mathrm{C}$ in January to $15.4{ }^{\circ} \mathrm{C}$ in July, with a mean annual temperature of $3.3{ }^{\circ} \mathrm{C}$. Mean annual precipitation is $53 \mathrm{~cm}$, with over half of the precipitation falling as snow (Wang et al. 2012).

\section{Field Methods}

Seedlings were censused in June of 2017 in twenty-nine 1-m ${ }^{2}$ seedling plots. Plots were established along eight $150-\mathrm{m}$ transects that were oriented parallel and spaced $50 \mathrm{~m}$ or $100 \mathrm{~m}$ apart to ensure inclusion of representative age classes and neighborhood densities.
Transects extended across the entire length of the stand to capture the full range of abiotic conditions and species composition. Seedling plots were spaced equidistantly along transects at 20-m intervals. Within each seedling plot, all seedlings were counted, identified to species, and aged by visually inspecting bud scars to determine year of establishment (Urza and Sibold 2013). Three hemispherical canopy images were taken at each seedling plot using a standard DSLR camera equipped with a wide-angle lens and mounted to a selfleveling tripod. Neighborhood basal area (BA) was determined by measuring the distance to and diameter at breast height $(\mathrm{DBH})$ of all trees exceeding $2.5 \mathrm{~cm} \mathrm{DBH}$ within $20 \mathrm{~m}$ of each seedling plot. The species of each neighboring tree was recorded, but neighboring species were not evaluated separately within the analysis due to model dimensionality limitations. A 20-m radius represents roughly 3 times the average diameter of the crowns of adult trees within this stand, which is a reliable estimate of the rooting zone and the region of biotic influence (Copenhaver-Parry and Cannon 2016). To determine soil fertility, 3 paired (anion and cation) Plant-Root Simulator $\left(\mathrm{PRS}^{\circledR}\right)$ probes were buried at the center and 2 corners of each seedling plot. PRS probes contain an ion-exchange resin membrane that attracts and absorbs available anions and cations (Western Ag Innovations Inc. 2017). PRS probes remained buried for 1 month and through several significant rain events to ensure sufficient detection of exchangeable ions and to reduce the impacts of initial soil disturbance (Harrison and Maynard 2014, Western Ag Innovations Inc. 2017). Following the 1-month burial period, probes were retrieved, rinsed with deionized water, and shipped to the Western Ag Innovations laboratory (Saskatoon, Saskatchewan) for processing. Several membranes were damaged during burial and retrieval, and soil ion data were ultimately only available for a subset of 24 seedling plots.

\section{Data Processing}

All field data were processed for inclusion as model covariates prior to model fitting. PRS probes were processed and analyzed at the Western Ag Innovations laboratory (Saskatoon, Saskatchewan). Probe analysis entails eluting and analytically measuring all absorbed 
TABLE 1. The mean, standard deviation (SD), minimum (Min), and maximum (Max) plot-level seedling counts of the 4 species of conifers censused in the twenty-nine $1-\mathrm{m}^{2}$ study plots.

\begin{tabular}{lrrrrr}
\hline Species & Mean & SD & Min & Max & $n$ \\
\hline Abies lasiocarpa & 28.4 & 22.6 & 0 & 64 & 24 \\
Picea engelmanii & 0.2 & 0.3 & 0 & 5 & 24 \\
Pinus flexilis & 1.5 & 1.4 & 0 & 5 & 24 \\
Pinus contorta & 0.4 & 0.6 & 0 & 2 & 24 \\
\hline
\end{tabular}

anions and standardizing anion quantity by burial period (Harrison and Maynard 2014, Western Ag Innovations Inc. 2017). Lab ion measurements were used to construct a soil evaluation factor (SEF). The SEF considers the ions that have an established influence on vegetation growth in forest soils and represents soil fertility at a given location with a single, comprehensive value ( $\mathrm{Lu}$ et al. 2002). We utilized a modified version of the SEF proposed by Lu et al. (2002):

$$
\begin{aligned}
\mathrm{SEF}= & {\left[\mathrm{Ca}^{2+}+\mathrm{Mg}^{+}+\mathrm{K}^{+}-\log (1+\mathrm{Al})\right] } \\
& \times\left(\mathrm{NO}_{3}^{-}+\mathrm{NH}_{4}^{+}\right)+5 .
\end{aligned}
$$

SEF values were calculated from PRS probe data for each of the 24 seedling plots. Nitrogen, potassium, calcium, and magnesium are the 4 essential plant macronutrients needed in the largest quantities by all plants, and aluminum is a relatively abundant metal in forest soils that restricts vegetative growth (Fahey and Yavitt 1988, Lu et al. 2002).

To determine light availability at individual seedling plots, hemispherical canopy photographs collected at each plot were processed in Image J (Schneider et al. 2012) to determine the percentage of pixels belonging to sky or canopy. Images were first converted to binary images to distinguish between sky and canopy, and the number of pixels belonging to each category was determined using the "Histogram" function in ImageJ. The average percentage of pixels belonging to sky was taken across 3 photographs for each seedling plot to represent light availability (Chianucci and Cutini 2012).

The size and distribution of adult trees within a $20-\mathrm{m}$ radius of each seedling plot were used to construct a neighborhood index. Neighborhood indices are commonly used to estimate competitive or facilitative effects (Weigelt and Jolliffe 2003). Although a large number of neighborhood indices have been developed with varying complexity, relatively simple distance-dependent indices without a light interception term have been shown to perform best in Rocky Mountain forests (Contreras et al. 2011). We utilized a neighborhood index (NI) adapted from Coates et al. (2013) that relies only on size and proximity of neighboring trees, where $i$ represents individual trees:

$$
N I=\sum_{i=1}^{n} \frac{B A_{i}}{\text { Distance }_{i}}
$$

Temperature and precipitation data corresponding with the year of seedling establishment were extracted for each seedling exceeding 1 year of age and less than 10 years of age. Only seedlings within this age range were deemed appropriate for inclusion in the analysis because (1) current year germinants have not yet experienced the dry summer conditions or winter and spring frosts that may be critical for determining plot-level seedling density, and (2) aging by bud scars was deemed inaccurate for individuals older than 10 years (Urza and Sibold 2013).

Climate data were extracted from the ClimateWNA database (Wang et al. 2012). ClimateWNA provides high-resolution climate point estimates downscaled from PRISM data (Daly et al. 2008) using bilinear interpolation (Wang et al. 2012). Climate variables were selected to represent those that are expected to influence specific recruitment processes including spring germination, summer survival, and winter survival. Ten different combinations of temperature and precipitation variables were selected to represent important hypothesized controls on A. lasiocarpa recruitment (Table 2). For example, A. lasiocarpa germination typically occurs in June in locations corresponding with the elevation of our study area, and so the combination of June mean temperature and spring precipitation was selected to represent the impact of climate on germination. Abies lasiocarpa seedling survival has been shown to be sensitive 
TABLE 2. The combinations of temperature and precipitation variables tested for inclusion as covariates in each of the seedling density models evaluated. All climate variables were extracted from ClimateWNA (Wang et al. 2012), and combinations were selected to represent hypothesized controls on recruitment of Abies lasiocarpa.

\begin{tabular}{|c|c|c|}
\hline Model & Climate covariates & Covariate abbr. \\
\hline Germination 1 & $\begin{array}{l}\text { Spring mean temperature }\left({ }^{\circ} \mathrm{C}\right) \\
\text { Spring precipitation }(\mathrm{mm})\end{array}$ & $\begin{array}{l}\text { Tave_sp } \\
\text { PPT_sp }\end{array}$ \\
\hline Germination 2 & $\begin{array}{l}\text { June mean temperature }\left({ }^{\circ} \mathrm{C}\right) \\
\text { Spring precipitation }(\mathrm{mm})\end{array}$ & $\begin{array}{l}\text { Tave_06 } \\
\text { PPT_sp }\end{array}$ \\
\hline Summer survival & $\begin{array}{l}\text { Summer mean temperature }\left({ }^{\circ} \mathrm{C}\right) \\
\text { May to September precipitation }(\mathrm{mm})\end{array}$ & $\begin{array}{l}\text { Tave_sm } \\
\text { MSP }\end{array}$ \\
\hline Annual & $\begin{array}{l}\text { Mean annual temperature }\left({ }^{\circ} \mathrm{C}\right) \\
\text { Mean annual precipitation }(\mathrm{mm})\end{array}$ & $\begin{array}{l}\text { MAT } \\
\text { MAP }\end{array}$ \\
\hline Frost exposure 1 & $\begin{array}{l}\text { Number of frost-free days } \\
\text { Mean annual precipitation }(\mathrm{mm})\end{array}$ & $\begin{array}{l}\text { NFFD } \\
\text { MAP }\end{array}$ \\
\hline Frost exposure 2 & $\begin{array}{l}\text { Frost-free period } \\
\text { Mean annual precipitation (mm) }\end{array}$ & $\begin{array}{l}\text { FFP } \\
\text { MAP }\end{array}$ \\
\hline $\begin{array}{l}\text { Frost exposure and } \\
\text { summer survival } 1\end{array}$ & $\begin{array}{l}\text { Number of frost-free days } \\
\text { May to September precipitation }(\mathrm{mm})\end{array}$ & $\begin{array}{l}\text { NFFD } \\
\text { MSP }\end{array}$ \\
\hline $\begin{array}{l}\text { Frost exposure and } \\
\quad \text { summer survival } 2\end{array}$ & $\begin{array}{l}\text { Frost-free period } \\
\text { May to September precipitation (mm) }\end{array}$ & $\begin{array}{l}\text { FFP } \\
\text { MSP }\end{array}$ \\
\hline Extreme conditions & $\begin{array}{l}\text { Temperature difference between } \\
\text { mean warmest month temperature and } \\
\text { mean coldest month temperature }\left({ }^{\circ} \mathrm{C}\right) \\
\text { Summer heat-moisture index }(\mathrm{MWMT} /[\mathrm{MSP} / 1000])\end{array}$ & SHM \\
\hline Temperature sensitivity & $\begin{array}{l}\text { Temperature difference between } \\
\text { mean warmest month temperature and } \\
\text { mean coldest month temperature }\left({ }^{\circ} \mathrm{C}\right) \\
\text { Mean annual precipitation }(\mathrm{mm})\end{array}$ & MAP \\
\hline
\end{tabular}

to spring frost exposure and summer drought (Maher and Germino 2006, Buck and St. Clair 2014), and climate variable sets were also constructed to represent these influences by including frost-free days, growing season precipitation, the difference in mean temperature between the warmest and coldest months, and a summer heat-moisture index (Table 2).

\section{Modeling Approach}

Multiple covariate sets were used to parameterize Bayesian multilevel regression models to evaluate the relative influences of environmental conditions on seedling density. The full set of model covariates included multiple combinations of temperature and precipitation variables, light availability, neighborhood index, and soil evaluation factor (Table 3). All covariates were scaled prior to inclusion in the model by dividing by 2 standard deviations. This scaling approach enables direct comparison of the magnitude of regression coefficients (Gelman 2014). Covariate sets were checked for correlation, and only covariates with correlations of $<0.7$ were included within the same model (Dormann et al. 2013). Covariates were used to fit a Bayesian multi- level generalized linear regression model using the brms package in R (Bürkner 2017, R Core Team 2017), which relies on the Stan Markov Chain Monte Carlo (MCMC) sampler for parameter estimation (Stan Development Team 2018). Stan implements a Hamilton Monte Carlo sampler with a No-U-Turn (NUTS) extension, which speeds up model convergence, particularly in the case of nonconjugate prior distributions (Hoffman and Gelman 2014). We utilized a multilevel Poisson regression model to account for the nested nature of seedling densities $(D)$ and covariates within plots $(i)$ and establishment years $(j)$. The model includes group-level intercepts for plot and year:

$$
\begin{aligned}
& D_{i, j} \sim \text { Poisson }\left(\exp _{i, j}\right) \\
& y_{i, j}=Z u+X \beta \\
& Z u=u_{0 j}+u_{1} \text { Temp }_{j}+u_{2} P P T_{j} \\
& X \beta=\beta_{0 i}+\beta_{1} \text { Light }_{i}+\beta_{2} N I_{i}+\beta_{3} \text { SEF }_{i}
\end{aligned}
$$

An uninformative multivariate normal prior was placed on group-level intercepts, and a weakly informative normal prior with mean 0 and standard deviation equal to 1 was placed on all population-level coefficients. All mod- 
TABLE 3. The covariates included in the candidate seedling density models. Model 5 (red type) was selected for the final model.

\begin{tabular}{|c|c|c|}
\hline Model & Group-level effects & Population-level effects \\
\hline 1 & Plot, Year & $\begin{array}{l}\text { Temp, Temp², PPT, PPT }{ }^{2} \text {, TempxPPT, Light, Light }{ }^{2} \text {, } \\
\text { NI, NI }{ }^{2}, \text { SEF, SEF }{ }^{2} \text {, NIxLight, CIxSEF }\end{array}$ \\
\hline 2 & Plot, Year & Temp, Temp ${ }^{2}$, PPT, PPT $^{2}$, Light, Light ${ }^{2}$, NI, NI ${ }^{2}$, SEF, SEF ${ }^{2}$ \\
\hline 3 & Plot, Year & Temp, PPT, TempxPPT, Light, NI, SEF, NIxLight, NIxSEF \\
\hline 4 & Plot, Year & Temp, Temp ${ }^{2}$, PPT, PPT², Light, Light ${ }^{2}$, NI, SEF \\
\hline 5 & Plot, Year & $\begin{array}{l}\text { Temp, Temp }{ }^{2} \text {, PPT, PPT2 }{ }^{2} \text { TempxPPT, Light, Light }{ }^{2} \text {, } \\
\text { NI, SEF, NIxLight, NIxSEF }\end{array}$ \\
\hline
\end{tabular}

els were run with 4 chains and for 2000 iterations, with the first 1000 iterations discarded as burn-in. This small number of iterations is consistent with typical convergence times for models fitted using the NUTS sampler (Bürkner 2017). Model convergence was assessed with the Gelman-Rubin convergence diagnostic; a value of 1 was taken to represent parameter convergence (Gelman and Rubin 1992). All model parameters reached convergence by 2000 iterations.

A model selection approach was implemented to determine the combination of covariates that best explained seedling density. Five models were fitted with different population-level effects structures that included various combinations of linear, quadratic, and interaction terms (Table 3). Each of the 5 models was fit using all 10 combinations of climate covariates to determine the combination of climate variables that has the strongest influence on A. lasiocarpa recruitment, resulting in a total of 50 fitted models. Candidate models were compared using approximate leave-oneout cross validation (LOO; Vehtari et al. 2017). LOO estimates out-of-sample pointwise predictive accuracy based on the sum of the posterior density given the data for each iteration of the model with an individual hold-out data point, and can be used to compare the relative fit of models fitted to the same data. Interpretation of LOO in a model comparison context is straightforward: the model with the smallest LOO indicator criterion represents the best fit (Vehtari et al. 2017). We used the loo function in the brms package to estimate the LOO indicator criterion for each fitted model and selected the model associated with the smallest LOO indicator criterion for all subsequent inference (Table 4).

Model fit was further evaluated by assessing the correlation between observed seedling density values and predicted seedling density values. Fitted coefficient estimates and associated $95 \%$ credible intervals were evaluated to determine the relative influence of each covariate on seedling density. Coefficients were deemed statistically significant when the 95\% credible interval did not include 0 . We also calculated the intraclass correlation coefficient (ICC) for the final model. This statistic represents the proportion of variance in seedling densities that is explained by the multilevel grouping structure after accounting for the effects of population-level covariates (Spiegelhalter et al. 2002). The ICC is calculated as the variance in the group-level residuals divided by the sum of the group-level and population-level residuals.

\section{RESULTS}

When comparing candidate models with the LOO indicator criterion, models including a reduced set of quadratic and interaction terms showed improved fit relative to other covariate structures (Table 4). Additionally, models including some measure of frost duration as a covariate representing temperature outperformed other candidate models. Ultimately, a model with a reduced set of quadratic and interaction terms, and number of frost-free days and mean annual precipitation representing climate, was identified as the best-fitting model. However, a number of other candidate models were within 2 deviance units of this best-fitting model, underscoring the relatively small contribution of quadratic terms, interaction terms, and climate to explained variance in seedling density (Table 4; Raftery 1995). The final fitted model showed minimal bias and strong fit according to observed versus predicted values $(r=0.99$, RMSE $=0.57$; Fig. 3).

Seedling density showed nonsignificant associations with the number of frost-free days, 


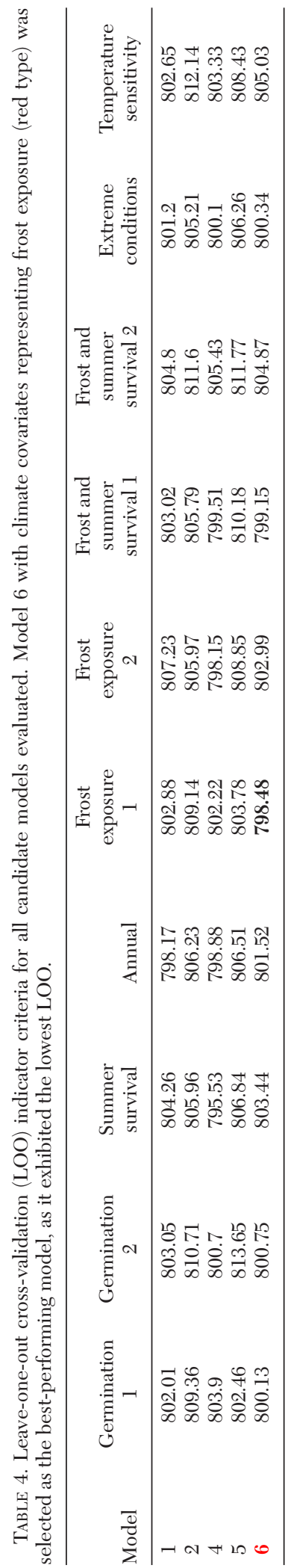

mean annual temperature, and their interaction in the year of establishment, and parameter estimates for climate effects were associated with relatively broad posteriors and high uncertainty (Fig. 4). Plot-level light availability also showed no significant association with seedling density. Seedling density declined significantly with increasing soil fertility; densities of 34 seedlings or more consistently occurred in plots with an SEF at or below 0.5 (SEF ranged from 0.155 to 2.34 across all plots with a mean SEF of 0.75; Fig. 4, 5). The interaction between NI and soil fertility was also significant, demonstrating a positive association with seedling density. However, the effect of NI alone was nonsignificant, indicating that much of this interactive effect is driven by soil fertility (Fig. 4). The highest seedling densities consistently occurred in plots with low soil fertility, but high seedling densities occurred with both high and low NI (Fig. 5). The ICC for the final model indicated that $\sim 60 \%$ of the variance in seedling density can be explained by the plot and year in which a seedling established, after accounting for the effects of climate, light, NI, and soil fertility $(\mathrm{ICC}=0.606)$.

\section{Discussion}

Consistent with our initial hypothesis, stand-level variables including temperature and precipitation showed little association with A. lasiocarpa seedling recruitment, while microsite factors, particularly soil fertility and the interaction between soil fertility and neighborhood index, were found to exert significant influences on seedling density (Fig. 4). The lack of a significant relationship with the comprehensive suite of climate variables that we evaluated is consistent with other studies that have evaluated the effects of both climate and microsite conditions on A. lasiocarpa seedling establishment in contrasting forest types (Stohlgren et al. 1998, LePage et al. 2000), and may indicate a decoupling of the microsite conditions experienced by seedlings from those represented by the freeair gridded climate data used in the models. Specifically, the forest canopy can strongly buffer seedlings from wind, frost, high solar irradiance, and temperature extremes, generating ground-level microclimate conditions that may be more conducive to seedling survival 


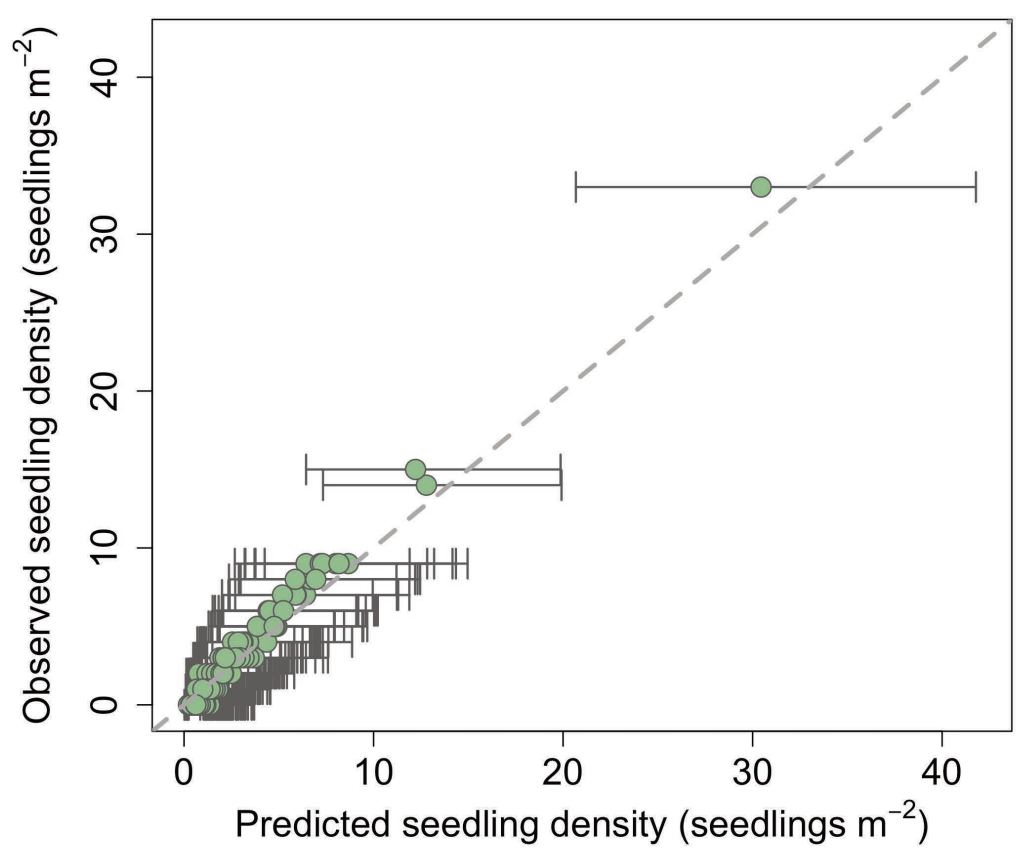

Fig. 3. The final model showed minimal bias across the range of data, producing predicted seedling density estimates that were similar to observed seedling densities $(r=0.99$, RMSE $=0.57)$. Green circles are posterior predictive means, and gray bars represent posterior predictive $95 \%$ credible intervals. The dashed line is the 1:1 reference, representing perfect fit.

than conditions beyond the forest canopy (Maher and Germino 2006, De Frenne et al. 2013, Dobrowski et al. 2015, Pyatt et al. 2016, Lenoir et al. 2017, Redmond and Kelsey 2018).

Despite the lack of significance between all of the climate variables we evaluated and seedling density, models including either the number of frost-free days or the frost-free period to represent temperature showed, in general, a better fit to the data than models including other temperature variables (Table 4). Indeed, A. lasiocarpa has been shown to be highly sensitive to frost exposure, though the impact of frost on seedling survival is magnified for seedlings establishing away from the protective cover of forest canopy or shrubs (Germino et al. 2002, Maher and Germino 2006). The location of all of our seedling plots beneath canopy cover likely explains the lack of a significant effect of frost exposure on seedling density, along with nonsignificant relationships between seedling density and other climate variables.

Alternatively, the nonsignificant relationships between seedling density and climate observed in our study could be attributed to the limited geographic range over which our data were collected. The strong elevation gradients that characterize the range of A. lasiocarpa correspond with high temperature variation, which may contribute to heterogeneity in community structure and ecological processes on a broader geographic scale (Sundqvist et al. 2013). However, while certainly limited in geographic scope, our findings are consistent with range-wide studies that have investigated climate-induced variation in recruitment across species' ranges. Seedling abundance patterns throughout North American forests have been repeatedly shown to be only weakly related to climate in broad-scale studies (Canham and Murphy 2016, Dallas and Hastings 2018, Copenhaver-Parry et al. 2019), and range-wide demographic patterns appear far more related to stand structure than climate (Thuiller et al. 2014, Dobrowski et al. 2015). While climate can explain a substantial portion of the variation in occurrence patterns of seedlings and adult trees in Rocky Mountain forests (Bell et al. 2014), the abundances of seedlings and adults, when present, are determined primarily by nonclimatic factors (Canham 


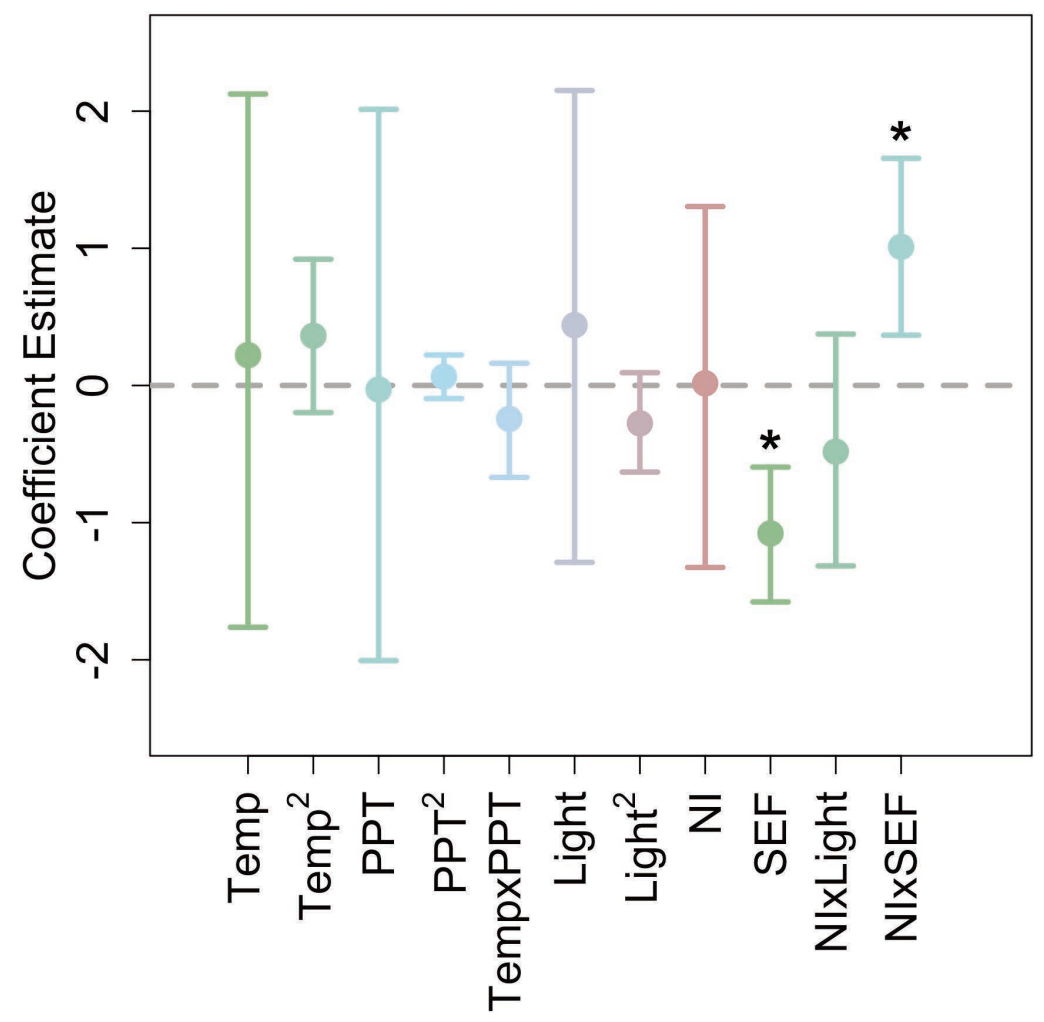

Fig. 4. Posterior mean estimates of population-level coefficients and associated $95 \%$ credible intervals indicate the significant effects (asterisks) of SEF and the interaction between NI and SEF on seedling density.

and Murphy 2016, Copenhaver-Parry et al. 2019).

Of the plot-level microsite conditions evaluated, only soil evaluation factor (SEF, an index of soil fertility), showed a significant and direct relationship with A. lasiocarpa seedling density. This was a surprising finding, given the relative abundance of research from more northern and high-elevation forest types demonstrating strong associations between A. lasiocarpa seedling densities and light availability or canopy openness (e.g. Knapp and Smith 1982, LePage et al. 2000, Lajzerowicz et al. 2004). We found no significant relationship between light availability and seedling density, and the effect of neighborhood index, which is related to canopy cover, was only significant in interaction with soil fertility (Figs. 4, 5). However, recent research by Redmond and Kelsey (2018) in subalpine sprucefir forests with varying degrees of overstory mortality demonstrated that A. lasiocarpa seedlings showed little response to variation in canopy cover, and irradiance was only significantly related to seedling density in stands with high overstory mortality. Other studies have also indicated that light levels in undisturbed stands may not be low enough to significantly inhibit seedling establishment (LePage et al. 2000, Stohlgren et al. 1998, Coates et al. 2013). Our study area had little overstory mortality, and irradiance may not have reached the levels necessary to significantly affect seedling density.

The significant negative relationship between soil evaluation factor (SEF) and A. lasiocarpa seedling density was surprising, given the notoriously low nutrient availability in Rocky Mountain forests, and particularly in those dominated by $P$. contorta (Fahey and Knight 1986). In our study, A. lasiocarpa seedling densities were highest in plots characterized by low SEF (Fig. 5). SEF was not correlated with litter accumulation, coarse woody debris, or soil $\mathrm{pH}$ across our study plots (data not shown), thus ruling out many potential 


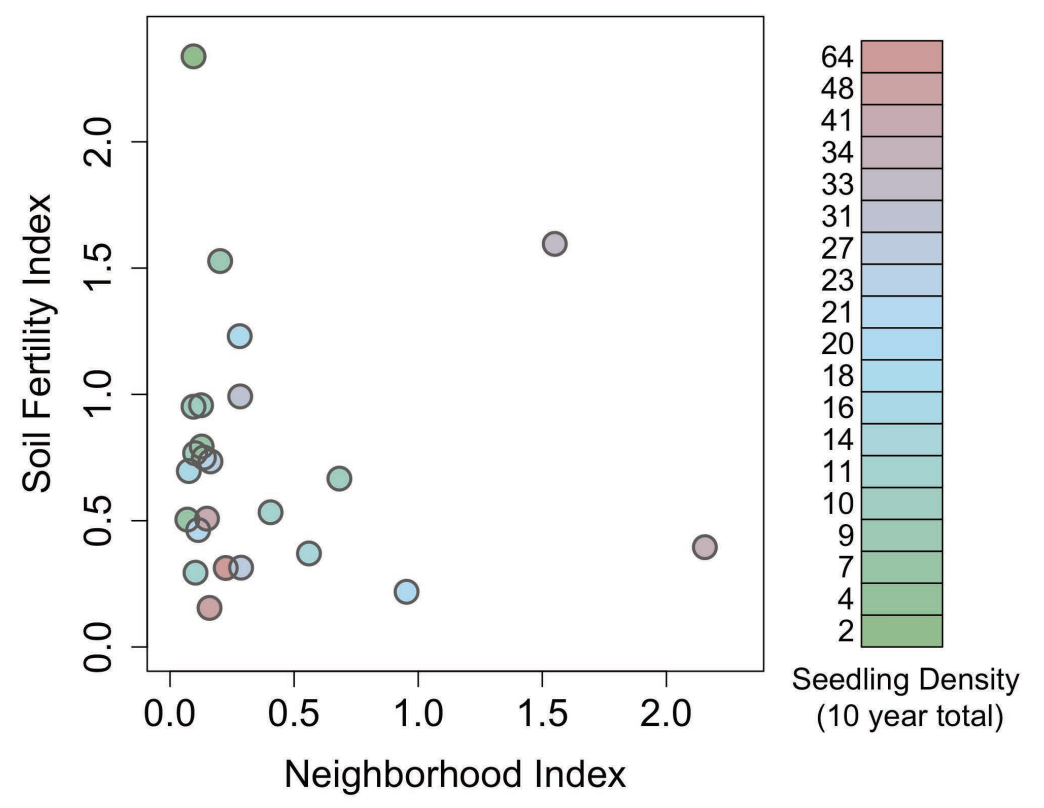

Fig. 5. The bivariate interaction of soil fertility index and neighborhood index was significantly associated with seedling density. Seedling density generally declined with soil fertility, although high seedling densities occurred with both high and low neighborhood index.

explanations for the importance of low SEF. Other studies have found close relationships between A. lasiocarpa establishment and substrate type in diverse forest types (e.g., LePage et al. 2000), but these findings are often contradictory. For example, Knapp and Smith (1982) found that A. lasiocarpa in a subalpine spruce-fir forest in southeast Wyoming tends to establish on thick litter layers, although Anderson and Winterton (1996), in a study also within spruce-fir forests, found lowest A. lasiocarpa germination rates on litter and highest rates on mineral soil. LePage et al. (2000) also observed highest A. lasiocarpa seedling densities on mineral soil, with lower densities on logs, litter, and moss, although these findings come from a northern mixed-conifer forest. Collectively, these findings, along with the results from our study, indicate that substrate type is unlikely to explain the SEF-seedling density relationship we observed.

In evaluating the component ions that contribute to the soil evaluation factor, we find that much of the variation in SEF is related to ammonium $\left(\mathrm{NH}_{4}{ }^{+}\right)$and nitrate $\left(\mathrm{NO}_{3}{ }^{-}\right)$availability, with the lowest SEF plots having virtually no available nitrate and little available ammonium (data not shown). Nitrogen availability in midelevation $P$. contorta-dominated forests in southeastern Wyoming is notoriously low, and most nitrogen is tightly retained in litter and aboveground biomass (Pearson et al. 1987). Indeed, all of our seedling plots had plant-available soil nitrogen levels that would be considered low. Nitrogen concentrations, as well as the concentrations of most other biologically important ions, are primarily transported with meltwater, and low ion concentrations are associated with regions of higher water flux; locations with low soil nitrogen availability, and low soil fertility in general, may represent locations along water flux pathways with greater soil moisture availability and transient pulses of soil nutrients (Fahey and Knight 1986, Fahey and Yavitt 1988). Buck and St. Clair (2014) found that soil moisture plays a central role in A. lasiocarpa germination and establishment patterns in mixed-species midelevation forests, and soil moisture is a likely mechanism to explain the strong negative relationship between SEF and A. lasiocarpa seedling density in our study. Soil moisture availability, particularly during the summer growing season, may also be greater in areas with lower neighboring tree 
density (low NI), as summer rains are often inadequate for soil moisture recharge where rooting zones are dense, and most available moisture is quickly taken up by tree roots via transpiration (Reynolds and Knight 1973, Fahey and Knight 1986). This mechanism is consistent with the significant interactive effect of SEF and NI on seedling density, and the concentration of high seedling densities in plots with low SEF and low NI (Fig. 5). Although 2 instances of high seedling densities in plots with high NI were observed (Fig. 5), these correspond with neighborhoods with unusually high adult $A$. lasiocarpa basal area, and probably represent particularly high $A$. lasiocarpa seed availability due to seed contributions by adult conspecifics.

Collectively, our findings indicate that $A$. lasiocarpa recruitment in this midelevation mixed-conifer forest is strongly related to soil fertility, and we posit that this may reflect a stronger underlying relationship with spatial variation in soil moisture availability. Indeed, $\sim 60 \%$ of the variance in A. lasiocarpa seedling densities within our model was explained by the plot and year structure after accounting for the effects of climate, light, NI, and SEF, indicating that unobserved processes occurring at the plot and year levels contribute substantially to A. lasiocarpa recruitment. Much of the plot-level variance may be attributable to the direct effects of soil moisture availability, a possibility corroborated by other studies emphasizing the importance of soil moisture for A. lasiocarpa seedlings (Knapp and Smith 1982, Buck and St. Clair 2014). Although we were unable to directly measure soil moisture availability in our study, this variable is perhaps deserving of greater research attention, particularly within the moisture-limited midelevation forests of the Rocky Mountains. In sum, our findings suggest that fine-scale spatial variation in soil resource availability may be an important mechanism underlying A. lasiocarpa recruitment success within this forest and may contribute to the maintenance of forest resilience by supporting structural heterogeneity and species diversity through persistent A. lasiocarpa recruitment.

\section{ACKNOWLEDGMENTS}

We thank Michael Salazar and Melissa Martin at the USDA Forest Service Medicine
Bow-Routt National Forest District for generously granting research permits on short notice; Greg Pappas for collecting, preparing, and submitting PRS probes; and Monique Nelson and Kellen Nelson for providing access to Pole Mountain fire history data. This research was supported by a grant from the Murdock Charitable Trust to P. CopenhaverParry (\#2015205), grants from the Richter Scholars Program to C.P. Murar and E.Z. Stephens, and the George Fox University Department of Biology.

\section{Literature Cited}

Agne, M.C., T. Woolley, and S. Fitzgerald. 2016. Fire severity and cumulative disturbance effects in the post-mountain pine beetle lodgepole pine forests of the Pole Creek Fire. Forest Ecology and Management 366:73-86.

Alexander, R.R., R.C. Shearer, and W.D. Shepperd. 1990. Abies lasiocarpa. Pages 60-70 in R.M. Burns and B.H. Honkala, editors, Silvics of North America. United States Department of Agriculture, Washington, DC.

Anderson, L.J., AND A.J. Winterton. 1996. Germination as a determinant of seedling distributions among natural substrates in Picea engelmannii (Pinaceae) and Abies lasiocarpa (Pinaceae). American Journal of Botany 83:112-117.

Bell, D.M., J.B. Bradford, and W.K. Lauenroth. 2014. Early indicators of change: divergent climate envelopes between tree life stages imply range shifts in the western United States. Global Ecology and Biogeography 23:168-180.

Buck, J.R., and S.B. St. Clair. 2014. Stand composition, proximity to overstory trees and gradients of soil moisture influence patterns of subalpine fir seedling emergence and survival. Plant and Soil 381:61-70.

Buma, B., and C.A. Wessman. 2011. Disturbance interactions can impact resilience mechanisms of forests. Ecosphere 2:1-13.

BüRKNER, P.C. 2017. Brms: an R package for Bayesian multilevel models using stan. Journal of Statistical Software 80:1-28.

Calder, W.J., And S.B. St. Clair. 2012. Facilitation drives mortality patterns along succession gradients of aspen-conifer forests. Ecosphere 3:1-11.

Canham, C.D., and L. Murphy. 2016. The demography of tree species response to climate: seedling recruitment and survival. Ecosphere 7:e01424.

Chianucci, F., And A. Cutini. 2012. Digital hemispherical photography for estimating forest canopy properties: current controversies and opportunities. iForest 5:290-295.

Coates, D.K., E.B. Lilles, and R. Astrup. 2013. Competitive interactions across a soil fertility gradient in a multispecies forest. Journal of Ecology 101: 806-818.

Collins, B.J., C.C. Rhoades, R.M. Hubbard, and M.A. BATTAGLia. 2011. Tree regeneration and future stand development after bark beetle infestation and har- 
vesting in Colorado lodgepole pine stands. Forest Ecology and Management 261:2168-2175.

Collins, B.J., C.C. Rhoades, J. Underhill, and R.M. HuBbard. 2010. Post-harvest seedling recruitment following mountain pine beetle infestation of Colorado lodgepole pine stands: a comparison using historic survey records. Canadian Journal of Forest Research 40:2452-2456.

Colorado Forestry Advisory Board. 2006. Report on the health of Colorado's forests: Special issue: lodgepole pine forests. Colorado Department of Natural Resources Division of Forestry, Denver, CO.

Contreras, M.A., D. Affleck, and W. Chung. 2011. Evaluating tree competition indices as predictors of basal area increment in western Montana forests. Forest Ecology and Management 262:1939-1949.

Copenhaver-Parry, P.E., AND D.M. Bell. 2018. Species interactions weakly modify climate-induced co-occurrence patterns. Journal of Vegetation Science 29: $52-61$.

Copenhaver-Parry, P.E., and E. Cannon. 2016. The relative influences of climate and competition on tree growth along montane ecotones in the Rocky Mountains. Oecologia 182:13-25.

Copenhaver-Parry, P.E., C.J.W. Carroll, P.H. Martin, AND M.V. TALLuTO. 2019. Multi-scale integration of tree recruitment and range dynamics in a changing climate. Global Ecology and Biogeography. https:// dx.doi.org/10.1111/geb.13012

Dale, V.H., L.A. Joyce, S. McNulty, R.P. Neilson, M.P. ayres, M.D. Flannigan, P.J. Hanson, L.C. Irland, A.E. Lugo, C.J. Peterson, ET AL. 2001. Climate change and forest disturbances. BioScience 51:723-734.

Dallas, T.A., AND A. Hastings. 2018. Habitat suitability estimated by niche models is largely unrelated to species abundance. Global Ecology and Biogeography $27: 1448-1456$.

Daly, C., M. Halbleib, J.I. Smith, W.P. Gibson, M.K. Doggett, G.H. Taylor, J. Curtis, and P.P. Pasteris. 2008. Physiographically sensitive mapping of climatological temperature and precipitation across the conterminous United States. International Journal of Climatology 28:2031-2064.

DAY, R.J. 1972. Stand structure, succession, and use of Southern Alberta's Rocky Mountain Forest. Ecology 53(3):472-478.

De Frenne, P., F. Rodriguez-Sanchez, D.A. Coomes, L. Baeten, G. Verstraeten, M. Vellend, M. Bernhardt-Romermann, C.D. Brown, J. Brunet, J. CoRNELIS, ET AL. 2013. Microclimate moderates plant responses to macroclimate warming. Proceedings of the National Academy of Sciences 110:18561-18565.

DeRose, J.R., AND J.N. Long. 2007. Disturbance, structure, and composition: spruce beetle and Engelmann spruce forests on the Markagunt Plateau, Utah. Forest Ecology and Management 244:16-23.

Dobrowski, S.Z., A.K. Swanson, J.T. Abatzoglou, Z.A. Holden, H.D. SAFFord, M.K. SChwarTZ, and D.G. GAVIN. 2015. Forest structure and species traits mediate projected recruitment declines in western US tree species. Global Ecology and Biogeography 24: 917-927.

Donato, D.C., M. Simard, W.H. Romme, B.J. Harvey, AND M.G. TURNER. 2013. Evaluating post-outbreak management effects on future fuel profiles and stand structure in bark beetle-impacted forests of Greater Yellowstone. Forest Ecology and Management 303: 160-174.

Dormann, C.F., J. Elith, S. Bacher, C. Buchmann, G. Carl, G. Carre, J.R. Garcia Marquez, B. Gruber, B. Lafourcade, P.J. Leitao, et aL. 2013. Collinearity: a review of methods to deal with it and a simulation study evaluating their performance. Ecography 36:27-46.

FAhey, T.J., AND D.H. KNight. 1986. Lodgepole pine ecosystems. Bioscience 36:610-617.

FaheY, T.J., AND J.B. YavitT. 1988. Soil solution chemistry in lodgepole pine (Pinus contorta ssp. latifolia) ecosystems, southeastern Wyoming, USA. Biogeochemistry 6:91-118.

Flannigan, M.D., M.A. Krawchuk, and W.J. De Groot. 2009. Implications of changing climate for global wildland fire. International Journal Wildland Fire 18: 483-507.

Fornwalt, P.J., C.C. Rhoades, R.M. Hubbard, R.L. HarRIS, A.M. FAIST, AND W.D. Bowman. 2018. Shortterm understory plant community responses to salvage logging in beetle-affected lodgepole pine forests. Forest Ecology and Management Scientific Journal 409:84-93.

Gelman, A. 2014. Scaling regression inputs by dividing by two standard deviations. Statistics in Medicine 27: 2865-2873.

Gelman, A., And D.B. Rubin. 1992. Inference from iterative simulation using multiple sequences. Statistical Science 7:457-511.

Germino, M.J., W.K. Smith, And A.C. Resor. 2002. Conifer seedling distribution and survival in an alpinetreeline ecotone. Plant Ecology 162:157-168.

GreEnE, D.F., AND E.A. Johnson. 1999. Modeling recruitment of Populus tremuloides, Pinus banksiana, and Picea mariana following fire in the mixedwood boreal forest. Canadian Journal of Forest Research 29:462-473.

HaRRison, D.J., AND D.G. MaYnaRd. 2014. Nitrogen mineralization assessment using PRS $^{\mathrm{TM}}$ probes (ionexchange membranes) and soil extractions in fertilized and unfertilized pine and spruce soils. Canadian Journal of Soil Science 94:21-34.

Harvey, B.J., D.C. Donato, and M.G. Turner. 2016. High and dry: post-fire tree seedling establishment in subalpine forests decreases with post-fire drought and large stand-replacing burn patches. Global Ecology and Biogeography 25:655-669.

Hoffman, M.D., and A. Gelman. 2014. The No-U-Turn Sampler: adaptively setting path length in Hamiltonian Monte Carlo. Journal of Machine Learning Research 15:1593-1623.

HolLing, C.S. 1973. Resilience and stability of ecosystems. Annual Reviews in Ecology and Systematics 4:1-23.

Hooper, D.U., F.S. Chapin, J.J. Ewel, A. Hector, P. Inchausti, S. Lavorel, J.H. LaWton, D.M. Lodge, M. LoREAU, S. NAEEM, ET AL. 2005. Effects of biodiversity on ecosystem functioning: a consensus of current knowledge. Ecological Monographs 75:3-35.

Johnstone, J.F., AND F.S. ChaPIN III. 2006. Fire interval effects on successional trajectory in boreal forests of northwestern Canada. Ecosystems 9:268-277.

Johnstone, J.F., F.S. Chapin III, J. Foote, S. Kemmett, K. Price, and L. Vlereck. 2004. Decadal 
observations of tree regeneration following fire in boreal forests. Canadian Journal of Forest Research 34:267-273

Kayes, L.J., and D.B. Tinker. 2012. Forest structure and regeneration following a mountain pine beetle epidemic in southeastern Wyoming. Forest Ecology and Management 263:57-66.

KNaPp, A.K., AND W.K. Smith. 1982. Factors influencing understory seedling establishment of Engelmann spruce (Picea engelmannii) and subalpine fir (Abies lasiocarpa) in southeast Wyoming. Canadian Journal of Botany 60:2753-2761.

Lajzerowicz, C.C., M.B. Walters, M. Krasowski, and H.B. Massicotte. 2004. Light and temperature differently co-limit subalpine fir and Engelmann spruce seedling growth in partial-cut subalpine forests. Canadian Journal of Forest Research 34: 249-260.

Lenoir, J., T. Hattab, and G. Pierre. 2017. Climatic microrefugia under anthropogenic climate change: implications for species redistribution. Ecography 40:253-266

LePage, P.T., C.D. Canham, K.D. Coates, and P. BerteMUCCI. 2000. Seed abundance versus substrate limitation of seedling recruitment in northern temperate forests of British Columbia. Canadian Journal of Forest Research 30:415-427.

Lu, D., E. Moran, and P. Mausel. 2002. Linking Amazonian secondary succession forest growth to soil properties. Land Degradation and Development 13: 331-343.

Maher, E.L., and M.J. Germino. 2006. Microsite differentiation among conifer species during seedling establishment at alpine treeline. Ecoscience 13: 334-341.

Meddens, A.J.H., A.T. Hudak, J.S. Evans, W.A. Gould, AND G. GONZÁLEZ. 2008. Characterizing forest fragments in boreal, temperate, and tropical ecosystems. Ambio 37:569-576.

NAEEM, S. 1998. Species redundancy and ecosystem reliability. Conservation Biology 12:39-45.

Nitschke, C.R., and J.L. Innes. 2008. Climatic change and fire potential in south-central British Columbia, Canada. Global Change Biology 14:841-855.

Noble, D.L., AND F. Ronco JR. 1978. Seedfall and establishment of Engelmann spruce and subalpine fir in clearcut openings in Colorado. RM-200, USDA Forest Service, Rocky Mountain Research Station, Fort Collins, CO.

Pearson, J.A., D.H. Knight, and T.J. Fahey. 1987. Biomass and nutrient accumulation during stand development in Wyoming lodgepole pine forests. Ecology 68:1966-1973.

Pretzsch, H. 2005. Diversity and productivity in forests: evidence from long-term experimental plots. Pages 41-64 in M. Scherer-Lorenzen, C. Körner, and E.D. Schulze, editors, Forest diversity and function. Ecological studies (analysis and synthesis). Volume 176. Springer, Berlin, Germany.

Pyatt, J.C., D.F. Tomback, S.C. Blakeslee, M.B. WunDER, L.M. Resler, L.A. Boggs, AND H.D. BevenCY. 2016. The importance of conifers for facilitation at treeline: comparing biophysical characteristics of leeward microsites in whitebark pine communities. Arctic, Antarctic, and Alpine Research 48:427-444.
Raftery, A.E. 1995. Bayesian model selection in social research. Sociological Methodology 25:111-163.

R Core Team. 2017. R: a language and environment for statistical computing. R Foundation for Statistical Computing, Vienna, Austria. https://www.R-project.org

Redmond, M.D., And K.C. Kelsey. 2018. Topography and overstory mortality interact to control tree regeneration in spruce-fir forests of the southern Rocky Mountains. Forest Ecology and Management 427: 106-113.

Reynolds, J.F., AND D.H. KNight. 1973. The magnitude of snowmelt and rainfall interception by litter in lodgepole pine and spruce-fir forests in Wyoming. Northwest Science 47:50-60.

Schneider, C.A., W.S. Rasband, and K.W. Eliceiri. 2012. NIH Image to ImageJ: 25 years of image analysis. Nature Methods 9:671-675.

Schoennagel, T., R.L. SherrifF, and T.T. Veblen. 2011. Fire history and tree recruitment in the Colorado Front Range upper montane zone: implications for forest restoration. Ecological Applications 21:2210-2222.

Schoennagel, T., M.G. Turner, and W.H. Romme. 2003. The influence of fire interval and serotiny on postfire lodgepole pine density in Yellowstone National Park. Ecology 84:2967-2978.

Spiegelhalter, D.J., N.G. Best, B.P. Carlin, and A. van DER LINDE. 2002. Bayesian measures of model complexity and fit. Journal of the Royal Statistical Society, Series B, Statistical Methodology 64:583-639.

Stan Development Team. 2018. Stan modeling language users guide and reference manual, version 2.18.9. https://mc-stan.org

Stohlgren, T.J., R.R. Bachand, Y. Onami, and D. BinkLEY. 1998. Species-environment relationships and vegetation patterns: effects of spatial scale and tree life-stage. Plant Ecology 135:215-228.

SundQvist, M.K., N.J. SandERs, AND D.A. WardLE. 2013. Community and ecosystem responses to elevational gradients: processes, mechanisms, and insights for global change. Annual Review of Ecology, Evolution, and Systematics 44:261-280.

Thuiller, W., T. Munkemuller, K.H. Schiffers, D. Georges, S. Dullinger, V.M. Eckhart, T.C. Edwards Jr., D. Gravel, G. Kunstler, C. Merow, ET AL. 2014. Does probability of occurrence relate to population dynamics? Ecography 37:1155-1166.

Turner, M.G. 2010. Disturbance and landscape dynamics in a changing world. Ecology 91:2833-2849.

Turner, M.G., D.C. Donato, and W.H. Romme. 2013. Consequences of spatial heterogeneity for ecosystem services in changing forest landscapes: priorities for future research. Landscape Ecology 28: 1081-1097.

Turner, M.G., T.G. Whitby, D.B. Tinker, and W.H. Romme. 2016. Twenty-four years after the Yellowstone Fires: are postfire lodgepole pine stands converging in structure and function? Ecology 97: $1260-1273$.

URZA, A.K., AND J.S. Sibold. 2013. Nondestructive aging of postfire seedlings for four conifer species in northwestern Montana. Western Journal of Applied Forestry 28:22-29.

VEblen, T.T. 1986. Age and size structure of subalpine forests in the Colorado Front Range. Bulletin of the Torrey Botanical Club 113:225-240. 
Vehtari, A., A. Gelman, and J. Gabry. 2017. Practical Bayesian model evaluation using leave-one-out cross-validation and WAIC. Statistics and Computing 27:1413-1432.

Wang, T., A. Hamann, D.L. Spittlehouse, and T.Q. Murdock. 2012. ClimateWNA-High-resolution spatial climate data for western North America. Journal of Applied Meteorology and Climatology 51: $16-29$.

Weigelt, A., And P. Jolliffe. 2003. Indices of plant competition. Journal of Ecology 91:707-720.

Westerling, A.L., M.G. Turner, E.A.H. Smithwick, W.H. Romme, AND M.G. RYan. 2011. Continued warming could transform Greater Yellowstone fire regimes by mid-21st century. PNAS 108:13165-13170.

Western Ag Innovations Inc. 2017. Manual for Plant Root Simulator $\left(\mathrm{PRS}^{\circledR}\right)$ probes. https://www.western ag.ca/innov

YaChI, S., AND M. LOREaU. 1999. Biodiversity and ecosystem productivity in a fluctuating environment: the insurance hypothesis. PNAS 96:1463-1468.

Received 16 November 2018 Revised 5 April 2019 Accepted 30 April 2019

Published online 25 November 2019 